\title{
SENSITIVITY AND SPECIFICITY OF "MINI BRAIN" IMAGE PATTERN TO DIAGNOSE MULTIPLE MYELOMA AND PLASMACYTOMA
}

\author{
SENSIBILIDADE E ESPECIFICIDADE DO ACHADO DE "MINI-BRAIN" PARA DIAGNÓSTICO \\ DE MIELOMA MÚLTIPLO E PLASMOCITOMA
}

SENSIBILIDAD Y ESPECIFICIDAD DE "MINI BRAIN" PARA DIAGNÓSTICO DE MIELOMA MÚLTIPLE Y PLASMOCITOMA

Ulysses de Oliveira Souza', Matheus Fernandes de Oliveira ${ }^{1}$, Lindolfo Carlos Heringer ${ }^{1}$, Jose Marcus Rotta ${ }^{1}$, Ricardo Vieira Botelho

1. Department of Neurosurgery, Hospital do Servidor Público Estadual de São Paulo, IAMSPE, São Paulo, Brazil.

\begin{abstract}
Introduction: "Mini brain" image pattern has been identified as a radiological sign for diagnosing multiple myeloma (MM) and solitary plasmacytomas in magnetic resonance imaging (MRI). However, there is still very little data on the frequency with which it can be observed, and its real diagnostic accuracy. Objetive: In this study, we present our case series, discuss sensitivity and specificity of "mini brain" in the diagnosis of multiple myeloma (MM)/plasmacytoma, and conduct a literature review. Methods: The study sample consisted of asymptomatic and/or symptomatic patients consecutively diagnosed with expansive vertebral disease. Patients were evaluated with MRI. A literature review was conducted on the relationship of the radiological sign "mini brain" and the diagnosis of multiple myeloma (MM) or plasmacytoma. Results: Forty-seven patients were evaluated consecutively. Among five patients diagnosed with multiple myeloma, four had an MRI pattern of "mini brain". The sensitivity of "mini brain" was $80 \%$. The specificity was $97.6 \%$. The accuracy was $95.8 \%$. Sensitivity and specificity were $100 \%$ when we considered differential diagnoses only with neoplastic lesions involving the spine. Conclusions: "Mini brain" is a feasible and reliable sign for the diagnosis of multiple myeloma/plasmacytoma, guiding physicians for adequate screening and treatment. Nevertheless, it should not replace pathological investigation after vertebral biopsy. Level of Evidence III; Study of case: Case-control study.
\end{abstract}

Keywords: Plasmacytoma; Magnetic resonance spectroscopy; Sensitivity and specificity.

\section{RESUMO}

Introdução. O padrão de imagem "Mini brain" foi identificado como um sinal radiológico para diagnosticar mieloma múltiplo e plasmocitomas solitários em ressonância magnética (MR). No entanto, ainda existem dados escassos sobre a frequência na qual ele pode ser observado ea real precisão diagnóstica. Objetivo: No presente estudo, apresentamos nossa série, discutimos a sensibilidade ea especificidade de"mini-brain" sobre o diagnóstico de mieloma múltiplo (MM)/ plasmocitoma e revisão da literatura. Métodos. A amostra do estudo consistiu de pacientes assintomáticos e/ou sintomáticos consecutivamente diagnosticados com doença vertebral expansiva. Os pacientes foram avaliados com RM. Realizou-se revisão da literatura sobre a relação do sinal radiológico "mini-brain" e o diagnóstico de mieloma múltiplo (MM) ou plamocitoma. Resultados. Quarenta e sete pacientes foram avaliados consecutivamente. Entre os cinco pacientes diagnosticados com mieloma múltiplo, quatro apresentavam padrão MR de "mini-brain". A sensibilidade do "mini-brain" foi de 80\%. A especificidade foi de 97,6\%. A acurácia foi de 95,8\%. A sensibilidade ea especificidade foram de 100\%, quando consideramos diagnósticos diferenciais somente com lesões neoplásicas. Conclusão. "Mini brain" é um sinal viável e confiável para diagnosticar mieloma múltiplo/plasmocitoma, orientando os médicos para triagem e tratamento adequados. No entanto, não deve substituir a investigação patológica após biópsia vertebral. Nível de Evidência III; Estudo de caso: Estudo caso-controle.

Descritores: Plasmocitoma; Espectroscopia de ressonância magnética; Sensibilidade e especificidade.

\section{RESUMEN}

Introducción: Se ha identificado un patrón de imagen "mini brain" como una señal radiológica para el diagnóstico de mieloma múltiple (MM) y plasmocitomas solitarios en resonancia magnética (RM). Sin embargo, todavía los datos sobre la frecuencia con la que se puede observar y su exactitud diagnóstica real son escasos. Objetivo: En el presente estudio, presentamos nuestra serie de casos, discutimos la sensibilidad y la especificidad del "mini brain" en el diagnóstico de mieloma múltiple/plasmocitoma y revisamos la literatura. Métodos: La muestra del estudio consistió en pacientes asintomáticos y/o sintomáticos consecutivamente diagnosticados con enfermedad vertebral expansiva. Los pacientes fueron evaluados con RM. Se realizó una revisión de la literatura sobre la relación entre la señal radiológica "mini brain" y el diagnóstico de mieloma múltiple o plasmocitoma. Resultados: Cuarenta y siete pacientes fueron evaluados consecutivamente. Entre los cinco pacientes diagnosticados con mieloma múltiple, cuatro tenían un patrón de resonancia magnética de "mini brain". La sensibilidad del "mini brain" fue del 80\%. La especificidad fue 97,6\%. La precisión fue 95,8\%. La sensibilidad y la especificidad fueron del 100\% cuando consideramos diagnósticos diferenciales únicamente con lesiones neoplásicas que afectan a la columna vertebral. Conclusiones: El "mini brain " es una señal factible y confiable para diagnosticar mieloma múltiple/plasmocitoma, que guía a los médicos para detección y tratamiento adecuados. Sin embargo, no debería reemplazar la investigación patológica después de la biopsia vertebral. Nivel de Evidencia III; Tipo de Estudio: Estudio de caso control.

Descriptores: Plasmocitoma; Espectroscopía de resonancia magnética; Sensibilidad y especificidad. 


\section{INTRODUCTION}

Multiple myeloma (MM) is a neoplasm with an incidence of approximately six in 100,000 . It is rare, corresponding to $1 \%$ of malignant and $13 \%$ of hematological neoplasms. It is characterized by renal failure, hypercalcemia, anemia, infection, and bone pain. ${ }^{1-5}$

Lesions are commonly found in the axial skeleton with lytic features. An overlapping condition may occur with association with multiple myeloma, however plasmacytomas may precede MM, and solitary plasmacytomas may be found as a single lytic lesion without signs of myeloma cells on bone marrow examination. ${ }^{1-5}$

Bone involvement in $\mathrm{MM}$ is characteristic, and vertebral fractures are common. However, several other metabolic, degenerative, neoplastic and infectious conditions may also involve the spine. Currently, when a lesion is noted on the image scan and no clinical evidence of myeloma is present, a biopsy is usually required to establish the diagnosis. Elucidating characteristic and specific radiological images to diagnose $\mathrm{MM}$ or plasmacytoma may warrant prompt and ideal treatment. ${ }^{1-5}$

"Mini brain" image pattern has been identified as a radiological sign to diagnose MM and solitary plasmacytomas in magnetic resonance (MRI). ${ }^{6-12} \mathrm{Axial}$ T2-weighted images of the T12 vertebral body highlight the cortical and radiated pattern ("mini brain" sign). However, there is still very little data on the frequency with which it can be observed and the real diagnostic accuracy. ${ }^{6-12}$

In this study, we present our series, discuss the sensitivity and specificity of "mini brain" in the diagnosis of MM/plasmacytoma, and conduct a review of the current literature.

\section{METHODS}

This is a retrospective study to correlate postoperative pathological reports with preoperative MRI findings, to determine sensitivity and specificity of "Mini Brain" pattern. The study sample consisted of asymptomatic and/or symptomatic patients consecutively diagnosed with expansive vertebral disease evaluated in the Spine Section service of our institution (Hospital do Servidor Público Estadual de São Paulo - IAMSPE) from January 2014 to January 2016.

Patients were evaluated in the preoperative period with a neurological examination and radiological investigation (X-ray, tomography and MRI). All patients were submitted to surgical procedures (biopsy or excision).

All images were analyzed by two senior neurosurgeons and one neuroradiologist. Their analyses were blind (they did not know the pathological report).

The project was approved by the Research Ethics Committee in IAMSPE (number 0141/2011). All the patients involved adhered to the ethical requirements, and signed informed consent forms.

\section{Review}

A literature review was conducted on the relationship between the radiological sign "mini brain" and the diagnosis of MM or plasmacytoma. The literature review was performed in the MEDLINE (via PubMed) database.

We included all available studies which described the finding. Articles published in English from 1964 to 2016 were considered for analysis.

\section{The search strategy used was detailed below:}

(("multiple myeloma"[MeSH Terms] OR ("multiple"[All Fields] AND "myeloma"[All Fields]) OR "multiple myeloma"[All Fields]) OR ("plasmacytoma"[MeSH Terms] OR "plasmacytoma"[All Fields] OR "plasmocytoma"[All Fields])) AND (("spine"[MeSH Terms] OR "spine"[All Fields]) OR ("spine"[MeSH Terms] OR "spine"[All Fields] OR "vertebral"[All Fields])) AND ("magnetic resonance spectroscopy"[MeSH Terms] OR ("magnetic"[All Fields] AND "resonance"[All Fields] AND "spectroscopy"[All Fields]) OR "magnetic resonance spectroscopy"[All Fields] OR ("magnetic"[All Fields] AND "resonance"[All Fields]) OR "magnetic resonance"[All Fields])
The searches were performed by two authors, independently, and disagreements were resolved by discussion.

\section{Statistics}

Parametric numerical data were expressed as mean \pm standard deviation, and nonparametric data, as median and percentages.

\section{RESULTS}

Forty-seven patients were evaluated consecutively, being submitted to diagnostic or therapeutic procedures, according to Figure 1.

There were 21 men and 16 women. The mean age of the patients was $65.4 \pm 23.6$ years. Among these patients, five had diagnoses of $\mathrm{MM}$ or plasmacytoma and 45 had other diagnoses. (Figure 1)

The patients with plasmacytoma/MM were three women and two men, with ages ranging from 48 to 83 years and a mean age of 63.6 years. Two patients presented with Frankel $\mathrm{C}$ and three with Frankel $\mathrm{E}$. The levels involved were, in each patient, T1, T2, T11, L1 and L3. The main symptom was pain in three patients and motor deficit in two patients. Radiological pattern was a biconcave lytic fracture. (Table 1)

Of the five patients diagnosed with MM, 4 had a pattern of "mini brain" in the MRI (Figures 2 and 3). The sensitivity of "mini brain" was $80 \%$. The specificity was $97.6 \%$ (among the other 42 patients with infiltrating lesions in spine, "mini brain" pattern was observed in 1 patient (spondylodiscitis)) (Figure 4). Accuracy for diagnosis was 95.8\%.

Sensitivity and specificity were $100 \%$ when we considered differential diagnoses only with neoplastic lesions involving the spine.

\section{Review}

The search returned 97 papers. After selecting works by title, 12 remained in the final evaluation. Among the 12, only six were specific for radiological image patterns for MM/plasmocytoma. ${ }^{6-12}$

Sha et al. reported a characteristic appearance in four cases out of six patients with plasmacytoma. MRI features were curvilinear areas of low signal intensity within the vertebra and/or cortical irregularity. ${ }^{6}$

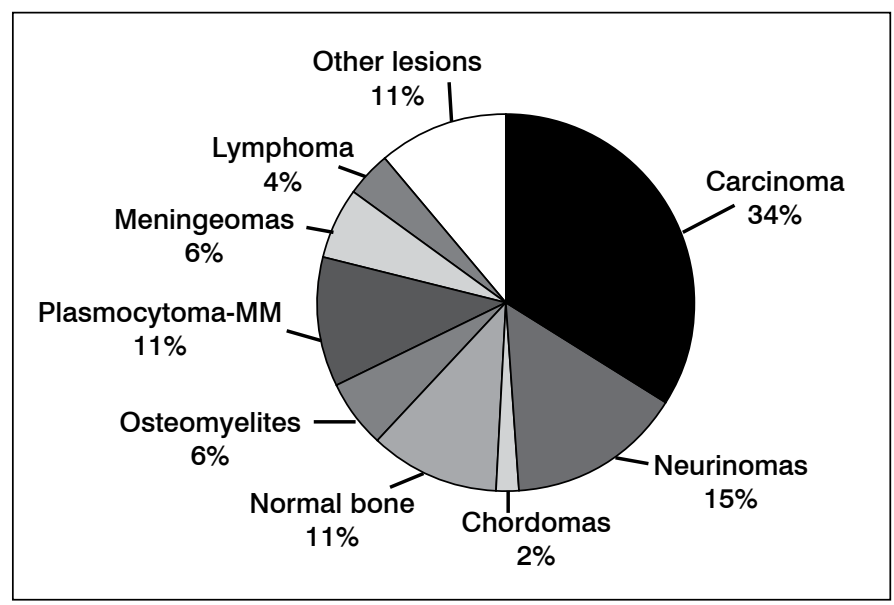

Figure 1. Pathological results of 47 patients evaluated.

Table 1. Data of 5 patients with MM/plasmacytoma.

\begin{tabular}{c|c|c|c|c|c|c}
\hline Patient & $\begin{array}{c}\text { Sex/ } \\
\text { Age }\end{array}$ & Frankel & Level & Symptom & $\begin{array}{c}\text { Radiological } \\
\text { aspect }\end{array}$ & Pathology \\
\hline 1 & M/51 & C & T11 & Dorsalgia & $\begin{array}{c}\text { Lytic biconcave } \\
\text { fracture }\end{array}$ & Plasmacytoma \\
\hline 2 & F/65 & E & T1 & Cervicalgia & $\begin{array}{c}\text { Lytic biconcave } \\
\text { fracture }\end{array}$ & Plasmacytoma \\
\hline 3 & F/71 & E & L3 & Cervicalgia & $\begin{array}{c}\text { Lytic biconcave } \\
\text { fracture }\end{array}$ & Plasmacytoma \\
\hline 4 & M/83 & C & L1 & $\begin{array}{c}\text { Motor } \\
\text { deficit }\end{array}$ & $\begin{array}{c}\text { Lytic biconcave } \\
\text { fracture }\end{array}$ & Plasmacytoma \\
\hline 5 & F/48 & E & T2 & Dorsalgia & $\begin{array}{c}\text { Lytic biconcave } \\
\text { fracture }\end{array}$ & Plasmacytoma \\
\hline
\end{tabular}




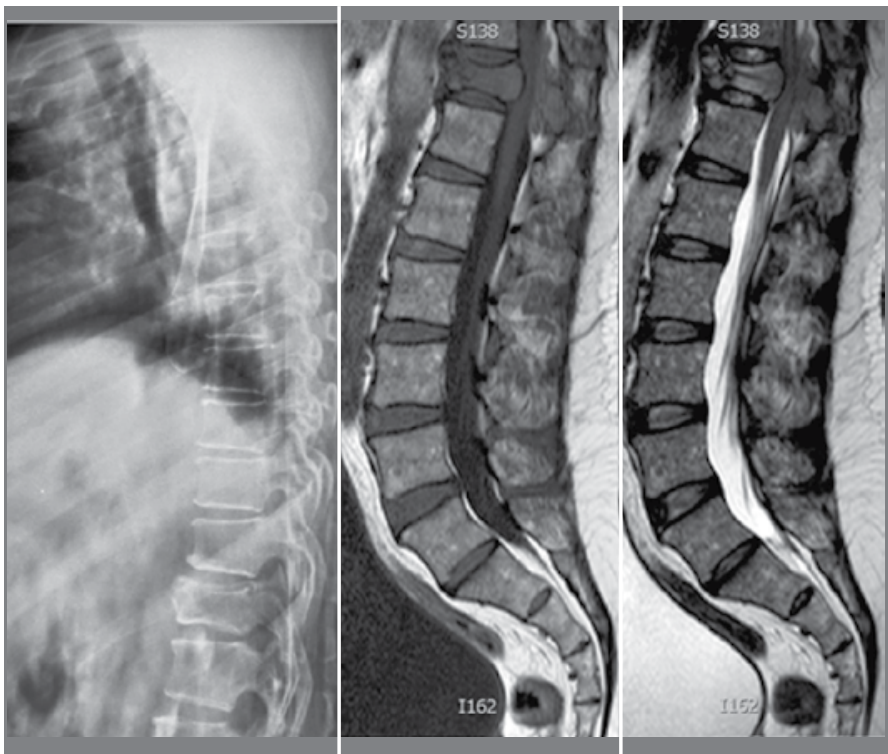

Figure 2. Typical image of MM/plasmacytoma patient with biconcave lytic thoracic fracture.

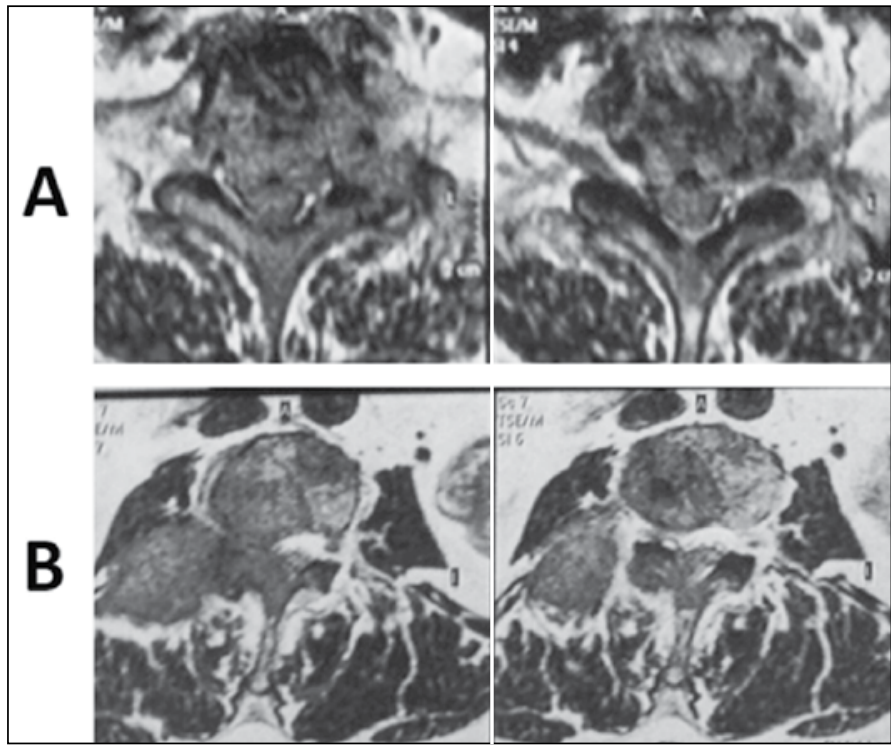

Figure 3. Images of patient with MM/plasmacytoma. In A, a typical finding of "mini brain" in axial MRI image. In B, the only case with MM/plasmacytoma without "mini brain" finding.

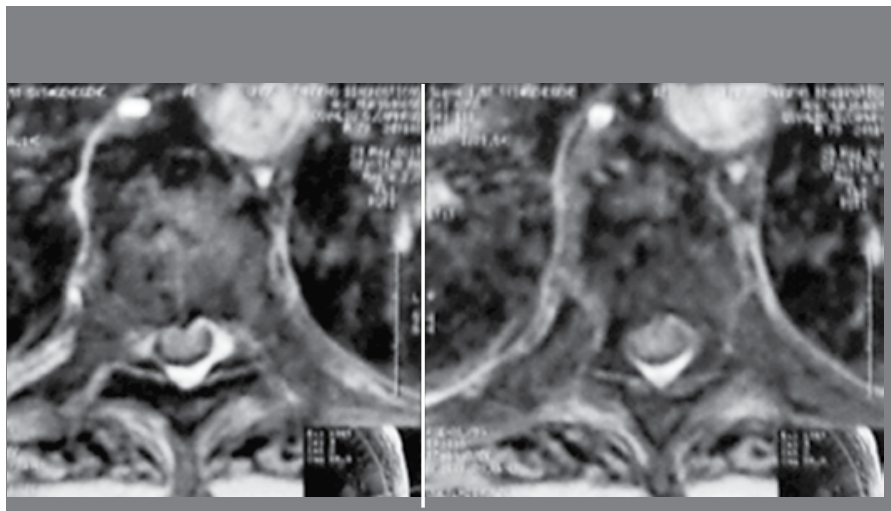

Figure 4. A case with "mini brain" appearance, however with a diagnosis of spondylodiscitis and no MM/plasmacytoma.
Major et al. studied 37 cases being $10 \mathrm{MM}$ /plasmacytomas and described a finding of high intensity of abnormal signal throughout the vertebral body and low linear signal intensity resembling brain grooves, naming this pattern the "mini brain" aspect. Furthermore, none of the other 27 patients with non-MM neoplastic lesions presented this finding. ${ }^{7}$

The authors go further and propose a "mini brain" appearance in an expansive lesion of the vertebral body as sufficiently pathognomonic of solitary plasmacytoma and even discuss whether there is need for biopsy. They also report that this finding was pathognomonic among neoplastic lesions, however other lesions could potentially present a similar pattern, as in a case of postoperative spondylodiscitis. ${ }^{7-8}$

Kaliswal et al. reported the diagnosis of a 50-year-old male patient with previous dorsalgia and lytic biconcave fracture in L4. They described the finding of "mini brain". They suggest that this finding is specific and should warrant prompt investigation for MM and plasmacytoma, although a biopsy is still necessary to determine pathological diagnosis. ${ }^{9}$

Subhas et al. described "mini brain" in a 70-year-old female patient with a lytic femur fracture. This report was the first to analyze "mini brain" outside the spine. They concluded that this finding strongly suggests MM/plasmacytoma in the axial or appendicular skeleton. ${ }^{10}$

Ferreira-Filho et al. reported a case of a 41-year-old woman with dorsalgia for six months and a lytic lesion in the lower thoracic spine. They also state that this finding is specific for diagnosis. ${ }^{11}$

Gupta et al. describe the case of a 55-year-old man with a lytic lesion in T12. Radiological diagnosis based on a finding of "mini brain" was subsequently supported by a pathological report. ${ }^{12}$

\section{DISCUSSION}

Multiple myeloma (MM) is a B-cell malignancy of antibody-secreting plasma cells expanding in the bone marrow. Symptoms develop as a result of anemia, immunosuppression, kidney failure, hypercalcemia, and bone destruction with painful pathologic fractures. ${ }^{1-5}$

Up to $80 \%$ of patients suffer vertebral compression fractures or pathological fractures of the long bones. These occur either as a result of diffuse osteoporosis or, more commonly, at the site of osteolytic lesions, as a consequence of both activation of osteoclasts and inactivation of osteoblasts mediated by the interaction of myeloma cells with the bone marrow microenvironment. ${ }^{1-5}$

The "mini brain" image pattern has been identified as a radiological sign for the diagnosis of MM and solitary plasmacytomas in MRI. Axial T2-weighted images of the T12 vertebral body highlight the cortical and radiated pattern ("mini brain" sign). Postcontrast T1weighted fat-saturated images show heterogeneous enhancement (arrowhead Mini brain sign represents cortical thickening and is most likely caused by lytic lesions). Thickened struts resemble sulci in the brain, leading to a small brain appearance. A "spoke-wheel" pattern has also been described. . $^{6} 12$

The characteristic appearance of thickened cortical struts may be due to chronic bone marrow compromise by disease with secondary compensation of bone strengthening in the cortical layer. This phenomenon is also described in Paget's disease and hemangiomas, however in these cases, the "mini brain" pattern is not seen. ${ }^{6-12}$

In our sample, all cases with MM and/or plasmacytoma were radiologically characterized by biconcave lytic fractures, with hypointensity in $\mathrm{T} 1$ and hyperintensity in T2. The levels most commonly involved are the lower thoracic levels. This is corroborated by other studies.

We found high sensitivity and specificity (80\% and 97.6\%) for the MM/plasmacytoma diagnosis using the "mini brain" MRI pattern among patients with any expansive lesion of spine. However, we observed a similar sign in a patient with spondylodiscitis and one patient with MM/Plasmacytoma did not present "mini brain". When considering only neoplastic lesions, the accuracy was 100\%.

Thus, "mini brain" is a feasible and reliable sign for diagnosing $\mathrm{MM} /$ plasmacytoma, and is helpful for application in clinical practice, 
guiding radiologists, clinical practitioners, hematologists and spine physicians to adequate screening and treatment. Nevertheless, as far as we know, "mini brain" should not prevent pathological investigation after vertebral biopsy, as there is a small but real possibility of misdiagnosis.

\section{Limitations}

The main limitation of this study is the relative rarity of $\mathrm{MM} /$ plasmacytoma patients with spinal findings, making it more difficult to determine a reliable and robust information of sensitivity. Further inclusion of evaluations of other centers is important in this matter.

\section{CONCLUSIONS}

Among spinal expansive lesions, "mini-brain" pattern had sensitivity of $80 \%$ and specificity of $97 \%$ for diagnosing MM/plasmacytoma. When considering only neoplastic lesions, the accuracy was $100 \%$.

This should be taken into account in clinical practice, facilitating and improving the diagnosis and management of MM/plasmacytoma patients.

All authors declare no potential conflict of interest related to this article.

CONTRIBUTION OF THE AUTHORS: UOS (0000-0002-1688-3632)*, MFO (0000-0003-1123-7583)*, RVB (0000-0002-9018-2746)^ designed paper. UOS, MFO, LCH(0000-0001-9571-7263)*, RVB collected the data. UOS, MFO, LCH, JMR(0000-0003-3452-4104)*, RVB analyzed the data, discussed the results and wrote the paper. ${ }^{*}$ ORCID (Open Researcher and Contributor ID).

\section{REFERENCES}

1. Terpos E, Dimopoulos MA, Moulopoulos LA. The Role of Imaging in the Treatment of Patients With Multiple Myeloma in 2016.Am Soc Clin Oncol Educ Book. 2016;35:e407-17.

2. He MX, Zhu MH, Zhang YM, Fu OG, Wu LL. ISolitary plasmacytoma of spine: a clinical radiologic and pathologic study of 13 cases]. Zhonghua Bing Li Xue Za Zhi. 2009:38(5):307-11

3. Angtuaco EJC, Fassas ABT, Walker R, Sethi R, Barlogie B. Multiple myeloma: clinical review and diagnostic imaging. Radiology. 2004; 231(1):11-23.

4. Palumbo A, Anderson K.Multiple myeloma. N Engl J Med. 2011;364(11):1046-60.

5. Miller JA, Bowen A, Morisada MV, Margetis K, Lubelski D, Lieberman IH et al.Radiologic and clinical characteristics of vertebral fractures in multiple myeloma. Spine J. 2015;15(10):2149-56.

6. Shah BK, Saifuddin A, Price GJ. Magnetic resonance imaging of spinal plasmacytoma. Clin Radiol. 2000;55(6):439-45
7. Major NM, Helms CA, Richardson WJ. The "mini brain": plasmacytoma in a vertebral body on MR imaging. AJR Am J Roentgenol. 2000;175(1):261-3.

8. Ehara S. "Mini brain" of plasmacytoma. AJR Am J Roentgenol. 2001;176(4):1076.

9. Kasliwal MK, O'Toole JE. Unique radiologic feature of spinal plasmacytoma: mini-brain appearance. Neurol India. 2011:59(3):486-7.

10. Subhas N, Bauer TW, Joyce MJ, Sundaram M. The "mini brain" appearance of plasmacytoma in the appendicular skeleton.Skeletal Radiol. 2008:37(8):771-4.

11. Ferreira-Filho LA, Pedroso JL, Sato EA, Yared JH, Barsottini OG, Bulle Oliveira AS et al.Teaching neuroimages: "mini brain" sign: a radiologic marker for vertebral solitaryplasmacytoma. Neurology. 2014;82(23):e210-1.

12. Gupta R, Mittal A, Mittal P, Kaur H, Sachdeva V, Mirchia K. Miniature brain in spine: the 'mini brain sign' in vertebral plasmacytoma. Postgrad Med J. 2016;92(1094):745-6. 